Research article

\title{
RENAL VASOGRAPHY IN MINK (MUSTELA VISON)
}

\author{
MRVIĆ Verica ${ }^{1 *}$, AVDIĆ Rizah², HADŽIOMEROVIĆ Nedžad², TANDIR Faruk², \\ PROKIĆ Branislav ${ }^{3}$, TOMAŠEVIĆ Ratko ${ }^{4}$, PROKIĆ Bogomir Bolka ${ }^{3}$
}

\begin{abstract}
${ }^{1}$ Department of Anatomy, Faculty of Veterinary Medicine, University of Belgrade, Belgrade, Serbia; ${ }^{2}$ Department of Anatomy and Histology with Embriology, Veterinary Faculty, University of Sarajevo, Sarajevo, Bosnia and Herzegovina; ${ }^{3}$ Department of Surgery, orthopedics and ophthalmology, Faculty of Veterinary Medicine, University of Belgrade, Belgrade, Serbia; ${ }^{4}$ Department of Gastroenterohepatology, Clinical Hospital Center Zemun, Faculty of Medicine, University of Belgrade, Belgrade, Serbia
\end{abstract}

(Received 19 June 2015, Accepted 18 October 2016)

\begin{abstract}
This paper presents the results of the research on renal blood vessels of the mink. The main goal of this research is to provide a unique insight in renal vessel constellation and thereby contributes to the amount and quality of the available data on the cardiovascular system of the mink, since the data found in the available literature regarding this specific field is rather poorly documented. Blood vessels of the mink kidney were studied by dissection and corrosion injection technique. The renal artery and its branches, and the lobar, interlobar and interlobular arteries are terminal arteries and they do not anastomose between each other. The arterial system is characterized by two independent vascular areas, supplied by the dorsal and ventral lobar artery. Lobar arteries divide the kidney horizontally into a dorsal and ventral half, while lobar veins divide it vertically into the cranial and caudal half. The renal vein is formed from the cranial and caudal lobar vein. The obtained results are compared with relevant literature findings on renal blood supply of a dog and other sympatric carnivores.
\end{abstract}

Key words: Mustela vison, mink, renal vasography, artery, veins.

\section{INTRODUCTION}

The mink (Mustela vison) is classified in the order of Carnivora, suborder Caniformia, superfamily Musteloidea, family Mustelidae. It used to be classified as Fissipedia, former suborder comprising the largely land-based families of the order Carnivora (fissipeds - toes separated from one another). The genus Mustela includes 16 species with a wide-ranging distribution extending throughout Eurasia, America and North Africa [1,2]. The American mink Mustela vison represents the focus of extensive conservation programmes throughout Europe, whereas it was naturalized as a species during the first half of the twentieth century due to its economic importance as a farmed furbearer [3]. It belongs to the the guild of semiaquatic mustelids, together with the

\footnotetext{
*Corresponding author: e-mail: vrmrvic@vet.bg.ac.rs
} 
group of small and middle-sized carnivores like the European otter Lutra lutra, the European polecat Mustela putorius, and the European mink Mustela lutreola. It has been shown that the presence of other predators can slow down its invasion front and can negatively affect its population [4]. Mustela vison is 0.7 to $1.1 \mathrm{~kg}$ in weight and its bushy tail accounts approximately one-third to one-half of its 46 to $76 \mathrm{~cm}$ length. Males can weigh up to twice as much as females [5].

The American mink is commonly associated with vegetated areas adjacent to water [6,7] exploiting inland waterways and coastal habitats [8]. This species has been used as an indirect bioindicator of mercury contamination of terrestrial ecosystems $[9,10]$, as well as a sentinel in environmental monitoring [11]. The intrasexual territoriality in minks is reflected in a larger home range than females and with male territories encompassing those of females [12,7]. Mating occurs in the middle of March, while parturition takes place from the last week of April up to the middle of May, with a peak at the beginning of May [13]. Females exhibit superfetation which renders them capable of ovulating more than once during a mating season and thereby give birth to one litter resulting from various ovulations and copulations with different males [14]. Average litter size is $4-5[15,16]$. The young are sexually mature at 10 months and can breed the following year [17].

The most perceptible differences between the wild and domestic mink appear to be the shortening of the muzzle and larger size in the domestic mink [18]. Several differences in skull dimensions between wild and domestic minks have also been noted. The findings indicate an increased frontal skull height in the domestic mink, a narrowed post-orbital region and reduced brain size and braincase volume [19]. Also, there are many similarities between the mink brain and the brain of similar animals [20]. In general, being able to locate important structures in the mink will be of great benefit towards understanding how structures are related to each other in the dog. If the same structure exist in both mink and carnivores (and most structures are the same), they are in the same relative location. Although many extensive vascular studies on mammals are performed, data regarding renal blood vessels in the mink (Mustela vison) is rather poorly documented. Therefore we are referencing the available data on renal bloodline of dogs and other carnivores [21-26], while comparing them to the data we have gathered regarding renal blood vessels of a mink.

The results reported in the relevant literature, regarding renal vasography of carnivores [37], were the starting point for this research. The aim of this work is to provide a unique insight in renal vessel constellation in order to contribute to the amount and quality of the available data on the cardiovascular system in the mink and describe the mink renal vascularization in sufficient detail $[36,38]$.

\section{MATERIAL AND METHODS}

Twenty kidneys were taken during necropsis from ten adult minks. The intrarenal anatomy was studied in three-dimensional endocasts of the kidney (intrarenal arteries 
and veins). We have removed the connective tissue from the renal surface by dissection, followed with preparation of the renal vein and artery to make them more accessible for injection. The casts were obtained by injection-corrosion technique [27]. For these purposes, we have used intravenous cannulas which were fixed to blood vessels with surgical thread and forceps. Injection of the renal blood vessels was conducted in such a way that we injected into either the afferent or efferent vascular renal system separately, in order to observe their flow and relationships. We have incised the Vena cava caudalis in order to allow the flushing of the vascular system. Upon this, the arterial and the venous system of mink were perfused with latex. Synthetic latex mixed with red pigment was injected into the thoracic aorta (aorta thoracica) with cautious pressure. Briefly, red latex was injected into the main trunk of the renal artery to fill in the arterial tree and blue latex was injected into the vena cava caudalis. After injection, the perirenal fat was removed and the kidneys were immersed in a bath of concentrated commercial hydrochloric acid for $48 \mathrm{hrs}$ to remove the organic matter. The strong acid has completely corroded the organ tissue, while keeping the plastic casts intact. The arterial system of each mink was studied in situ. The same method was used for the perfusion of the venous system - the perfusion compound was latex colored with blue pigment, injected through the vena cava caudalis. The names of the branches of the renal blood vessels were given in accordance to the current anatomical terminology Nomina Anatomica Veterinaria 2012 [28].

\section{RESULTS}

The renal arteries of the mink, aa. renis, arise from the abdominal aorta at the level of the third lumbar vertebrae - the right renal artery arises a bit more cranially than the left renal artery. Just before reaching the hilum, the renal artery of the mink branches out into the dorsal and ventral artery (Figure 1). The ureter and renal pelvis are separated by lobar arteries.

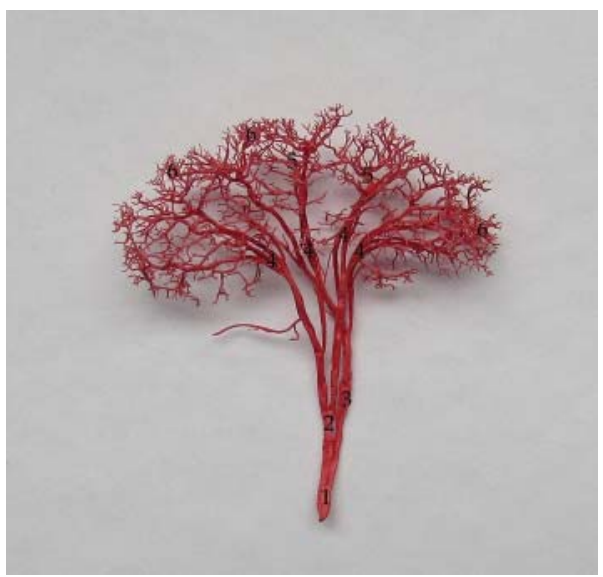

Figure 1. Renal artery of the right kidney - corrosion cast. 1. a. renalis, 2. ventral branch of the renal artery 3. dorsal branch of the renal artery 4. aa. interlobares, 5. aa. arcuatae, 6. aa. interlobulares 
Lobar renal arteries in the mink constitute two completely independent vascular areas. There are no anastomosis between these areas, since each of the lobar arteries vascularizes one half of a kidney. However, lobar arteries often vary in capacity, which results in the difference in size of the vascular area constituted by these arteries.

At the hilum the dorsal and ventral lobar artery divide dichotomously into the cranial and caudal branch of the lobar artery. Each of the cranial and caudal branch of the dorsal lobar artery, as well as cranial and caudal branch of the ventral lobar artery, divide dichotomously into two interlobular arteries.

Therefore, in both dorsal and ventral half of the mink kidney four interlobular arteries are constituted (Figure 2), aa.interlobulares renis dorsalis and aa. interlobulares renis ventrales. Both dorsal and ventral interlobular arteries can show further division, most often dichotomous interlobular arteries are terminal arteries, which do not show any anastomosis between themselves, or inside the single vascular area, or with interlobular arteries of the other vascular area (Figure 3).

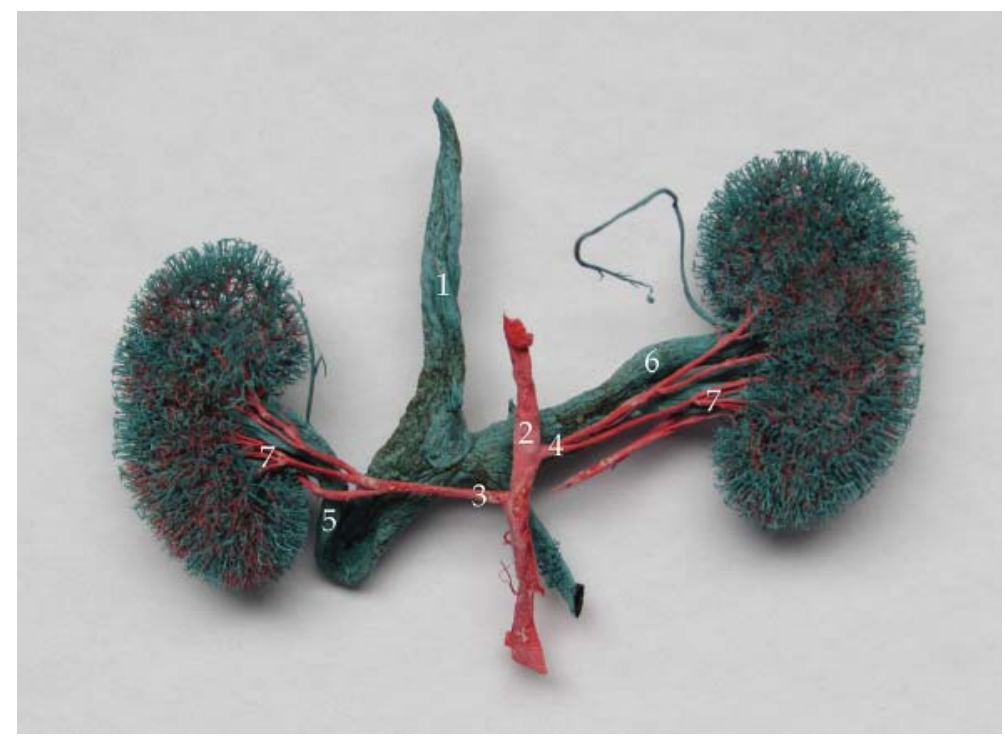

Figure 2. Dorsal aspect of arterial and venal vascularization in the kidney of the mink corrosion cast. 1. v. cava caudalis, 2. aorta, 3. a. renalis dextra, 4. a. renalis sinistra, 5. v. renalis dextra, 6. v. renalis sinistra, 7 . dorsal and ventral branches of renal artery

The cranial pole of the kidney is vascularized by branches of the cranial dorsal and ventral interlobular artery, while the caudal pole is vascularized by branches of the last caudal dorsal and interlobular artery. In some cases, aa. poli, can originate only from the dorsal or ventral interlobular arteries. On that base, we concluded that the origin of aa. poli in mink kidney can vary.

Interlobular arteries have a radial course. They flow between the lobes and reach the base of the pyramids. Aa. Interloburales are directed peripherally, multiply and branch 
towards the internal, medium and outer third of the kidney sheath and end in numerous afferent arteroioles, thus structuring a capillary network of glomerules. Interlobular arteries and arteries arcuates in the mink form aa. pelvicae. Blood evacuation happens through the cranial and caudal lobular vein, $v$. lobaris cranialis and $v$. lobaris caudalis (Figure 4), which interflow into thr renal vein outside the hilum. $v$. lobaris cranialis includes cranial branches of the lobular dorsal and ventral artery, while v. lobularis caudalis lies between the caudal branches of the lobular dorsal and ventral artery.

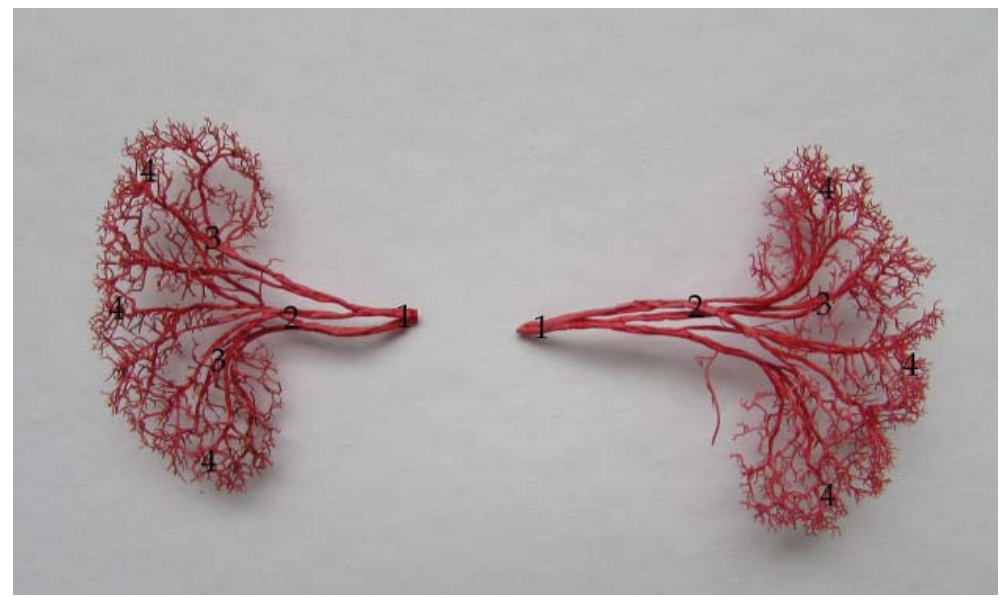

Figure 3. Arterial vascularization of the left (A) and right (B) kidney in the mink - corrosion cast. 1. a. renalis, 2. dorsal and ventral branches of the renal artery, 3. aa. interlobares, 4. aa. interlobulares

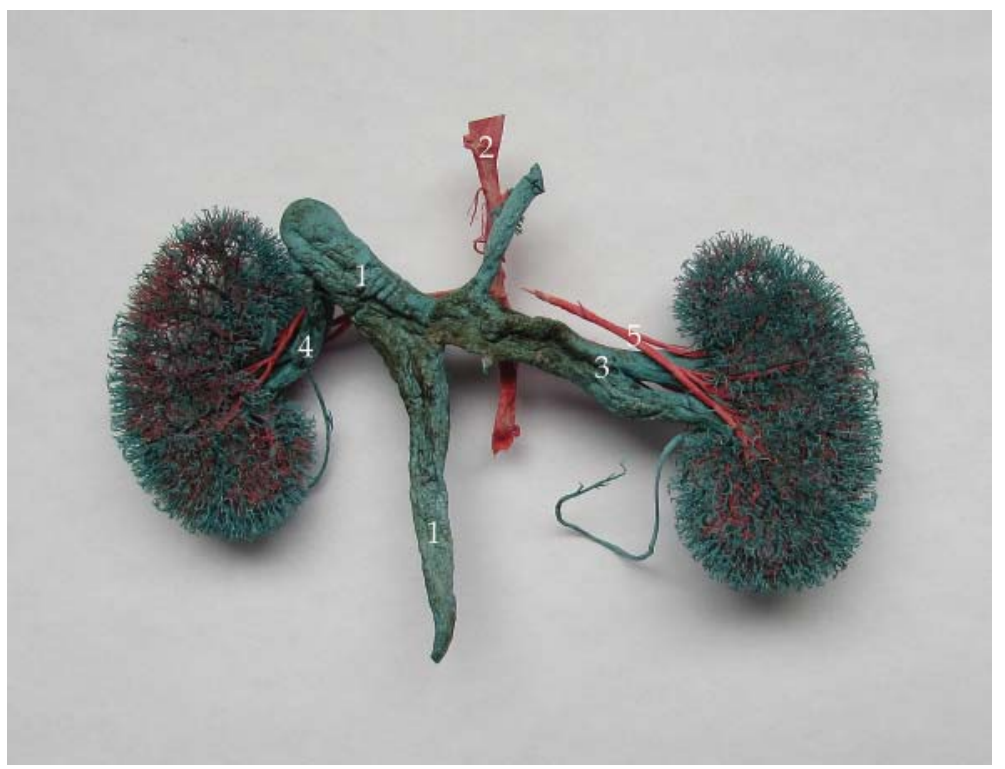

Figure 4. Ventral aspect of arterial and venal vascularization in the kidney of the mink corrosion cast. 1 . $v$. cava caudalis, 2 . aorta, 3. v. renalis sinistra, 4. v. renalis dextra, 5. a. renalis sinistra 
The cranial and caudal lobular vein originate (Figure 5) from the basin of the cranial dorsal and ventral interlobar and interlobular veins, in which interflow numerous aa. arcuatae on the border between the core and sheath. Hence, the cranial and caudal lobular veins develop two drainage areas, cranial and caudal. Differently from the vascular area of the lobular arteries, whose border coincides with the horizontal plane, the border of the drainage venal area coincides with the vertical plane passing through the kidney hilum.

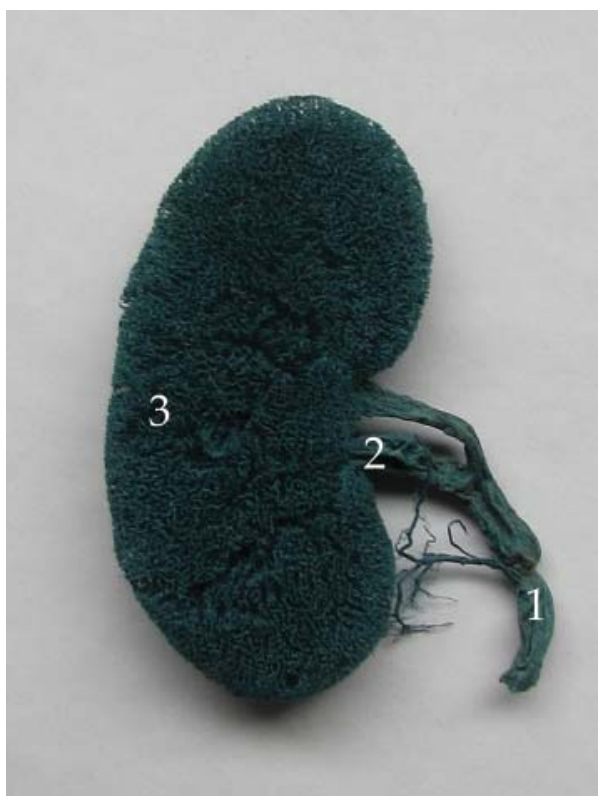

Figure 5. Corrosion cast of venal blood vessels of the kidney in the mink. 1. v. renalis, 2. $v$. interlobaris, 3. $\mathrm{vv}$. interlobulares

\section{DISCUSSION}

A recent study whose results generate and annotate mink transcript sequences representing more than 16000 known genes, reported that about 136000 of the assembled contigs, match the dog genome at more than 17000 unique gene locations [29]. The American mink and domestic dog manifest as sympatric carnivore species. Accordingly, reported dog renal artery research findings represent a sustainable solution for the comparison of the obtained results. Investigation the bifurcation of the abdominal aorta in mink and dog and cases of identified double renal arteries were described and compared by a number of authors [30]. Studies identified the occurrence of multiple renal arteries in a few percent of the dogs observed [31]. Similarly multiple renal arteries were rarely noted in the raccoon $\operatorname{dog}(5 \%)$ [32], and in the blue fox $(2.5 \%)$, [33].

Renal arteries play an important role in the absorption and filtering processes. It is observed that often two left renal arteries are established in the mink, as well as in the 
dog. There is a difference regarding the number of renal arteries in findings by Jain et al. [34] who reported three renal arteries in dog kidneys. In some cases, two left renal arteries represent the dorsal and ventral lobar artery, since their branches structure two vascular areas, i.e. the dorsal and ventral. In other cases, one of these arteries is less prominent. It represents the interlobular artery, since it branches only in one part - caudal or ventral of dorsal or ventral vascular area. Neither case exhibited variations in branching of renal arteries in a sense of diminished independence of the dorsal and ventral vascular area. Renal arteries emerge in the lateral walls of the abdominal aorta, caudally from the place of separation of the cranial mesenteric artery. In a $\mathrm{dog}$, this emergence occurs between the $2^{\text {nd }}$ and $3^{\text {rd }}$ lumbar vertebrae. The right renal artery appears more cranially than the left renal artery. The right renal artery is also somewhat longer than the left renal artery. Both renal arteries branch multiply before reaching the kidney to lobular and interlobular branches. Branches that vascularize the adrenal glands (aa. adrenales caudales) separate directly from renal arteries or from the abdominal aorta. The renal arteries of the mink, aa. renis, arise from the abdominal aorta at the level of the third lumbar vertebrae - the right renal artery arises a bit more cranially than the left renal artery. The course of the renal artery in the mink is similar to that of domestic carnivores. Just before reaching the hilum, the renal artery of the mink branches out into the dorsal and ventral artery. The ureter and renal pelvis are separating lobar arteries. Similarly to the dog lobar renal arteries in the mink constitute two completely independent vascular areas. There is no anastomosis between these areas, since each of the lobar arteries vascularizes one half of the kidney. However, lobar arteries often vary in capacity, which results in the difference in size of the vascular area constituted by these arteries.

Two main arteries, i.e. the cranial branches of the dorsal and ventral division of the renal artery, involved the dog kidney cranial pole. This relationship between intrarenal arteries and the collecting system of the cranial pole is similar to that in humans and pigs $[27,35]$. Therefore, this similarity would support the use of the dog as an animal model for urologic procedures in the cranial pole. Either cranial and caudal branches, or only the caudal branch of the dorsal division of the renal artery supply the dorsal mid-zone. However, the ventral mid zone region was irrigated from both cranial and caudal branches or only from the caudal branch of the ventral division of the renal artery. The midzone region of the dog presented the most varied arterial supply as happens in man and pigs $[27,35]$ and also in the mink. The caudal pole received caudal branches from both dorsal and ventral divisions of the renal artery and the collecting system of the caudal pole was supplied by branches of these two arteries. The left renal vein in the dog is longer than then right one, crosses the aorta anteriorly, and receives several tributaries during its course, such as the left gonadal vein, the urethral vein, and the suprarenal vein. The left renal vein communicates with a variable number of lumbar veins and the retroaortic and prevertebral venous plexi, which may serve as possible collateral venous drainage pathways through the pericapsular path (19). According to the presented results it may be concluded that the renal veins and arteries of the mink exhibit similarities to those of thedog in terms of branching. 
Focus of this research was on renal vascularization in mink (Mustela vison). This research will be extended with renal vascularization and innervation in the light of sexual dimorphism. Results of this research provide a significant contribution towards renal vasography from the anatomical aspect. Thus, a platform for further investigation of mink renal vascularization is provided, applicable for research in similar fields.

\section{Authors' contributions}

VM and RA have made substantial contributions to conception and final approval of the version to be published - defined the objective and the hypothesis of the study, specified sample group and determined experimental methods. NH and FT conducted the experimental research, tested the hypothesis, collected and analyzed the obtained research results. BP considered aspects related to the accuracy of the work and established the possible further investigations regarding the study presented in the paper. RT participated in the research design and coordination and helped to prepare complete manuscript. BBP reviewed the open relevant literature and evaluated the feasibility of testing the hypothesis.

\section{Declaration of conflicting interests}

The author(s) declared no potential conflicts of interest with respect to the research, authorship, and/or publication of this article.

\section{REFERENCES}

1. Macdonald DW: The new encyclopaedia of mammals. Oxford, United Kingdom: Oxford University Press; 2001.

2. Chapman JA, Feldhamer GA, Thompson BC: Wild Mammals of North America. Baltimore, Maryland: The Johns Hopkins University Press; 1982, 1147.

3. Lopez-Giraldez F, Gomez-Moliner B, Marmi J, Domingo-Roura X: Genetic distinction of American and European mink (Mustela vison and Mustela lutreola) and European polecat (Mustela putorius) hair samples by detection of a species-specific SINE and a RFLP assay. J Zool 2005, 265:405-410.

4. Bonesi L, Macdonald DW: Impact of released Eurasian otters on a population of American mink: A test using an experimental approach. Oikos 2004, 106:9-18.

5. McVey M, Hall K, Trenham P, Soast A, Frymier L, Hirst A: Wildlife Exposure Factors Handbook. Washington DC, United States: US Environmental Protection Agency; 1993.

6. Melero Y, Palazón S, Bonesi L, Gosàlbez J: Feeding habits of three sympatric mammals in NE Spain: The American mink, the spotted genet, and the Eurasian otter. Acta Theriol 2008, 53:263-273.

7. Dunstone N: The mink. Acta Ther 1994, 1:109-111.

8. Dunstone N, Birks JDS: Activity budget and habitat usage by coastal-living mink (Mustela vison). Act Zool Fenn 1993, 174:89-191. 
9. Loukmas JJ: Criteria for quantifying mink (Mustela vison) habitat quality in great lakes basin. Ph.D. Dissertation, Southern Illinois University, Carbonade, USA, 1998.

10. Yates DE, Mayack DT, Munney K, Evers DC, Mayor A, Kaur T, Taylor RJ: Mercury levels in mink (Mustela vison) and river otter (Lontra canadensis) from northeastern North America. Ecotoxicology 2005, 14:263-274.

11. Persson S, Brunström B, Bäcklin B, Kindahl H, Magnusson U: Wild mink (Neovison vison) as sentinels in environmental monitoring. Acta Vet Scand 2012, 54:S1-S9.

12. Macdonald DW, Rushton S: Modelling space use and dispersal of mammals in real landscapes: a tool for conservation. J Biogeogr 2003, 30:607-620.

13. Bäcklin B, Madej A, Forsberg M: Histology of ovaries and uteri and levels of plasma progesterone, oestradiol-17 $\beta$ and oestrone sulphate during the implantation period in mated and gonadotrophin-releasing hormone-treated mink (Mustela vison) exposed to olychlorinated biphenyls. J Appl Toxicol 1997, 17: 297-306.

14. Hauberg Andersen N: Effect of stress on reproduction in farmed male mink (Neovison vison)-behavioral and hormonal traits characterizing male mink reproductive success. M.Sc. Thesis, Aarhus University, Aarhus, Denmark, 2013.

15. Wren CD, Stokes PM, Fischer KL: Mercury levels in Ontario mink and otter relative to food levels and environmental acidification. Can J Zool 1986, 64:2854-2859.

16. Bartoszewicz M, Zalewski A: American mink Mustela vison diet and predation waterfowl in the Słonsk Reserve, western Poland. Folia Zool 2003, 52:225-238.

17. Jedrzejewska B, Sidorovich VE, Pikulík MM, Jedrzejewski W: Feeding habits of the otter and the American mink in Białowieża Primeval forest (Poland) compared to other Eurasian population. Ecography 2001, 24:165-180.

18. Kruska DCT, Sidorovich VE: Comparative allometric skull morphometrics in mink (Mustela vison) of Canadian and Belarus origin. Mammal Bio 2003, 68:257-276.

19. Tamlin A, Bowman J, Hackett D: Separating wild from domestic American mink Neovison vison based on skull morphometrics. Wildl Biol 2009, 15:266-277.

20. Milanović V, Mrvić V, Teodorović V, Milosavljević P, Prokić B, Avdić R: Morphology investigation of the mink s brain (Mustela vison). Acta Vet-Beograd 2013, 63:337-345.

21. Mrvić V: Atlas komparativne anatomije domaćih životinja. Beograd, 2006.

22. Ozudogru Z, Ozdemir D: Intrarenal arterial patterns of the wolf (Canis lupus). Vet Med Czech 2005, 50:411-414.

23. Miladinović Ž, Jablan-Pantić O: Blood vesels of the fox kidney (Alopex Lagopus). Acta VetBeograd 1975, 25:247-253.

24. Christensen G: Circulation of blood through the canine kidney. Amer J Vet Res 1952. 13:236-245.

25. Kürtül I, Dursun N, Özcan S: Relation of arterial vascularization of the kidney and adrenal gland of the german shepherd dogs. J Fac Vet Med Univ Istanbul 2002, 28:65-71.

26. Raj JU, Hillyard R, Kaapa P, Anderson J, Gropper M: Pulmonary vascular pressure profile in 2-3-week-old,5-6-week-old and adult ferrets. Respir physiol 1990, 82:307-315.

27. Sampaio FJ, Aragao AH: Anatomical relationship between the intrarenal arteries and the kidney collecting system. J Urol 1990, 143:679-681.

28. International Committee on Veterinary Gross Anatomica Nomenclature: Nomina anatomica veterinaria, $5^{\text {th }}$ Ed.(revised version), Hannover, Columbia, Ghent, Saporo, 2012. 
29. Christensen K, Anistoroaei R: An American mink (Neovison vison) transcriptome. Anim Genet 2014, 45:301-303.

30. Wiland C, Indykiewicz P: Multiple renal arteries (Aa. renales) in mink and dog. Elec J Poli Agri Univ 1999, 2.

31. Kosik O: Variace vetvi aortae abdominalis u psa. Biologicke opisy Wysoke Skoly Zverolekarsske 1923, 2:1-23.

32. Brudnicki W, Jablonski R, Skoczylas B: Przypadek wielokrotnych tetnic nerkowych aa. renalesu jenota (Nycterentes procyonoides Gray). Zesz Nauk ATR Bydgoszcz 1986, 140:25-28.

33. Wiland C, Knasiecka V: Przypadki wielokrotnych tetnic nerkowych u norki i lisa niebieskiego. Rocz WSR Poznan 1970, 49:107-111.

34. Jain RK, Dhingra LD, Kumar S, Sharma DN: Vascularization of kidneys in dogs (Canis familiaris). Indian J Anim Sci 1985, 55:406-409.

35. Pereira-Sampaio MA, Favorito LA, Sampaio FJ: Pig kidney: anatomical relationships between the intrarenal arteries and the kidney collecting system. J urol 2004, 172:2077-2081.

36. Fuller PM, Huelke DF: Kidney vascular supply in the rat, cat and dog. Acta Anat Basel 1973, 84:516-522.

37. Marques-Sampaio BP, Pereira-Sampaio MA, Henry RW, Favorito LA, Sampaio FJ: Dog kidney: anatomical relationships between intrarenal arteries and kidney collecting system. Anat Rec Hoboken 2007, 290:1017-1022.

38. Daescu E, Zahoi DE, Motoc A, Alexa A, Baderca F, Enache A: Morphological variability of the renal artery branching pattern: a brief review and an anatomical study. Rom J Morphol Embryol 2012, 53:287-291.

\section{VAZOGRAFIJA BUBREGA KANADSKE LASICE (MUSTELA VISON)}

MRVIĆ Verica, AVDIĆ Rizah, HADŽIOMEROVIĆ Nedžad, TANDIR Faruk, PROKIĆ Branislav, TOMAŠEVIĆ Ratko, PROKIĆ Bogomir Bolka

Predmet rada je vaskularni sistem bubrega kanadske lasice (Mustela vison). U dostupnoj literaturi se ne nalazi mnogo podataka o vaskularizaciji bubrega kanadske lasice, koja kao i domaći karnivori pripada suvozemnim karnivorima. Obzirom na to, u radu su korišćeni literaturni podaci o bubrežnom krvotoku domaćih karnivora, uglavnom psa, i izvršeno je poređenje dobijenih rezultata. Zbog oskudnosti podataka, rezultati ovog ispitivanja predstavljaju svojevrstan doprinos proučavanju kardiovaskularnog sistema kanadske lasice. Materijal korišćen prilikom ovog istraživanja nalazi se u kolekciji katedre za Anatomiju, histologiju i embriologiju Veterinarskog fakulteta Univerziteta u Sarajevu, Bosna i Hercegovina. U bubrege životinja, u arterijski, odnosno venski sistem, ubrizgan je in situ lateks obojen crveno za arterije i plavom bojom za vene. Uočeno je da se bubrežna arterija pre hilusa deli na dorzalnu i ventralnu lobarnu arteriju (a. lobaris dorsalis i a. lobaris ventralis). Lobarne arterije odvojene su ureterom koji je postavljen centralno i pelvis renalis-om. Svaka lobarna arterija vaskulariše svoju polovinu bubrega, 
i svaka obrazuje najčešće po četiri interlobarne arterije koje ne anastomoziraju između sebe. Evakuacija krvi odvija se preko kranijalne i kaudalne lobarne vene (v. lobaris cranialis i $v$. lobaris caudalis). Za razliku od vaskularnog područja lobarnih arterija koje se nalaze u horizontalnoj ravni, drenažno područje vena se nalazi u vertikalnoj ravni koja prolazi kroz bilus renalis. 